\title{
Involvement of Information Technology in the Presentation of Historical Architectural Monument
}

\author{
Využití současných informačních technologií \\ při prezentaci architektonické památky
}

\section{Ing. arch. Lenka ŠTĚPÁNKOVÁ}

Tutor: doc. Ing. arch. Maxmilián Wittmann, Ph.D.; Ústav urbanismu, Fakulta architektury, Vysoké učení technické v Brně, Česká republika

E-mail address: xastepankoval@stud.fa.vutbr.cz

\begin{abstract}
While working on the renovation project for only partially preserved architectural monuments, the authors can typically choose either to restore only the genuine elements, or to replace missing pieces through replicas. Contemporary presentation techniques, including 3D modeling, virtual reality and augmented reality make it possible to combine these attitudes. The building can be kept in its preserved shape and its original appearance can be presented using some of the aforementioned techniques. The example of Chateau at the Brno Exhibition Centre suggests that such techniques are also suitable for a situation in which the architectural monument intended for renovation has actually never been completed. The aforementioned digital technologies can not only be used for final presentation, but also to discuss and find the right method of renovation, as they make it possible to share the ideas within the professional community worldwide without the need to travel and physically meet.
\end{abstract}

KEYWORDS: architectural monument; presentation; information technology; virtual reality; 3D modeling

\begin{abstract}
ABSTRAKT: Při obnově architektonických památek nedochovaných v původní podobě stojí autoři projektu rekonstrukce vždy před dilematem, zda usilovat o původní vzhled památky pomocí výroby replik, nebo se omezit na rekonstrukci autentických prvků. Současné prezentační techniky zahrnující 3D modelování, virtuální realitu a rozšířenou neboli augmentovanou realitu nabízí nové možnosti, jak oba uvedené
\end{abstract}


přístupy sladit. Památku je tak možné ponechat v reálně dochované podobě a zároveň představit její originální vzhled. Příklad zámečku na brněnském výstavišti ukazuje, že tento prŕstup může být zvlášt vhodný v situaci, kdy má být předmětem obnovy památka, která nebyla v zamýšlené podobě zcela dokončena. Digitální technologie je možné využít nejen pro finální prezentaci, ale také při modelování alternativních řešení ve fázi odborné diskuze předcházející samotné rekonstrukci. Př́nosem tohoto postupu je i možnost zapojení mezinárodní vědecké komunity bez nutnosti osobního setkávání.

KLÍČOVÁ SLOVA: památky; informační technologie; prezentace; virtuální realita; 3D modelování

\section{Úvod}

Díky dnešnímu rozvoji informačních technologií a jejich pronikání do prakticky všech oborů lidské činnosti se objevují stále další způsoby a možnosti jejich využití. Dochází k tomu, že stále více různé agendy se přesouvá do virtuálního prostředí a zvyšuje se počet digitálně gramotných uživatelů v populaci. Opatření proti pandemii covidu-19, která byla v průběhu roku 2020 přijata v řadě zemí v Evropě i ve světělı, tento trend v mnoha směrech zvýraznila a urychlila. Cílem tohoto textu je na příkladu zámečku na brněnském výstavišti ukázat, jaké jsou konkrétní možnosti využití informačních technologií při péči o architektonické památky v průběhu jejich zkoumání, při projekčních pracích při jejich obnově a v neposlední řadě také při jejich prezentaci a zpř́istupnění veřejnosti. Kromě představení jednotlivých technik a jejich využití je záměrem poukázat přitom také na konkrétní problémy, které mohou vyvstat v praktické rovině.

\section{Zámeček na brněnském výstavišti}

Zámeček na brněnském výstavišti je vhodným referenčním př́kladem $\mathrm{z}$ více důvodů. Jedná se o kulturní památku, která je součástí většího a významného památkového souboru. Brněnské výstaviště, jehož součástí zámeček je, představuje v evropském i světovém měřítku unikátní př́íklad dochované avantgardní výstavní architektury z meziválečného období ${ }^{2}$ a má proto jako památka moderní architektury potenciál oslovit nejen odborníky na památkovou péči a zájemce o architekturu, ale také širší kulturní veřejnost včetně zahraničních návštěvníků.

Část interiérů zámečku upravoval ve dvacátých letech minulého století architekt Adolf Loos pro rodinu průmyslníka Viktora Bauera. $V$ důsledku společenského a politického vývoje se později, po roce 1945, zámeček stal na dlouhá desetiletí součástí veletržního areálu a byl využívaný jako administrativní budova, což značně přispělo k potlačení jeho 
rezidenčního charakteru. Z původního vybavení interiérů se dochovaly pouhé fragmenty, jako mramorové obložení v hlavním reprezentativním sále a vestavěný nábytek. Provedení těchto prvků je pro Loose natolik typické, že se povědomí o této jeho realizaci uchovalo, avšak po dlouhá desetiletí šlo o fakt známý pouze historikům architektury a zástupcům památkové péče, zatímco pro běžné publikum zámeček prakticky přestal existovat. Ani odborníkům však nebyla známa původní podoba interiérů podle Loosových návrhů ani podrobnější okolnosti jejich vzniku. Důležitý obrat představoval výzkum Jany Kořínkové zahájený v roce 2017, díky němuž se na základě dobových fotografií a archivních dokumentů podařilo objasnit skutečný rozsah Loosových úprav a částečně i okolnosti pozdějšího zániku interiérư${ }^{3}$. Nově odhalené skutečnosti umožňují zámeček zasadit do širšího kontextu Loosova díla ${ }^{4}$, což přirozeně vyvolává potřebu komunikace se znalci jeho díla včetně zahraničních expertů.

Pro běžné zájemce $\mathrm{z}$ řad laické veřejnosti jsou kromě Loosova díla důležité také okolnosti jeho vzniku. V př́padě zámečku lze na životním příběhu Viktora Bauera a jeho rodiny objasnit dopady historických událostí na konkrétní osoby a zprostředkovaně také na architektonické památky. Tento úhel pohledu nabízí na zámečku aktuálně probíhající výstava ${ }^{5}$, při níž jsou návštěvníkům zpř́stupněné některé z interiérů s dochovanými originálními interiérovými prvky; jiné však stále zůstávají veřejnosti nepř́stupné.

Národní památkový ústav a Muzeum hlavního města Prahy v souvislosti se 150. výročím architektova narození vyhlásily rok 2020 Rokem Adolfa Loose. K této iniciativě se následně připojila řada institucí a organizací s vlastním kulturním programem pořádaným při této př́ležitosti. Na zámečku brněnského výstaviště je instalovaná zmiňovaná výstava a objekt je zařazený do projektu Brněnský architektonický manuál jako jedno zastavení na architektonické stezce Po stopách Adolfa Loose ${ }^{6}$. Při festivalu Open House Brno v dubnu 2020 byly interiéry zámečku zpř́stupněné formou online prohlídky. Další online prohlídka zámečku proběhla v červenci $2020 \mathrm{v}$ rámci programu Adolf Loos - Pioneer of Modern Living ${ }^{7}$, organizovaného sítí Českých center v zahraničí.

Na říjen 2020 je v Brně v rámci Roku Adolfa Loose plánováno sympozium věnované dílu Adolfa Loose a workshop věnovaný obnově památek moderní architektury se zvláštním zaměřením na dílo Adolfa Loose ${ }^{8}$, kde má být mimo jiné diskutován možný budoucí způsob obnovy zámečku včetně interiérů. $V$ př́padě úvah o možné obnově interiérů je však třeba zohlednit, že hlavní reprezentativní sál nebyl nikdy kompletně dokončen a nedochovala se ani podrobná dokumentace návrhu. Podoba ostatních místností, které byly plně zařízené, se dochovala pouze na fotografiích a nejsou zatím dostupné žádné autentické kusy vybavení. Jakým způsobem a do jaké míry by tedy bylo možné interiéry obnovit a prezentovat veřejnosti, musí být nepochybně předmětem diskuze. Účast zahraničních odborníků a badatelů na workshopu na toto téma je plánována, může však být 
ohrožena $v$ př́padě nepříznivého vývoje epidemiologické situace. $V$ takovém případě připadá v úvahu alternativní způsob jejich zapojení do odborné debaty formou elektronické komunikace nebo sdílení obsahu přes internet.

\section{Prezentační a komunikační techniky}

Pro současná multimédia je charakteristické rychlé tempo inovací, kdy konkrétní hardware nebo software může být zastaralý už po několika letech. Oblast informačních technologií je také vysoce konkurenční prostředí, ve kterém stále vzniká mnoho nových aplikací, $\mathrm{z}$ nichž se však pouze některým podaří se prosadit a šířji se uplatnit. Z tohoto důvodu není ambicí tohoto př́spěvku popsat konkrétní technologie, nýbrž soustředit se podrobněji na obecné principy a v této rovině popsat př́nosy využití nových multimediálních prezentačních možností a upozornit na některá možná úskalí.

Prezentační a komunikační technikou se pro účely tohoto textu rozumí způsob, jak co nejlépe pomocí současných multimediálních technologií a sítového připojení zprostředkovat vjemy z prostoru a informace o architektonické památce někomu, kdo není fyzicky přítomný na místě. K tomu účelu musí být vytvořen digitální obsah, který je umístěn $\mathrm{v}$ datovém úložišti. Uživatelé mají následně prostřednictvím sítě $\mathrm{k}$ obsahu př́stup a podle záměru tvůrce obsahu jej mohou pouze prohlížet nebo do něj různým způsobem také zasahovat. Schematicky je proces znázorněný na obr. 1.

PAMÁTKA

UŽIVATELÉ

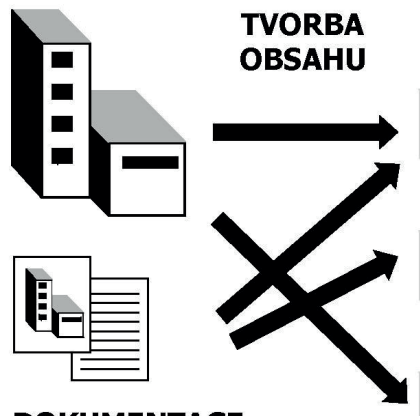

DOKUMENTACE

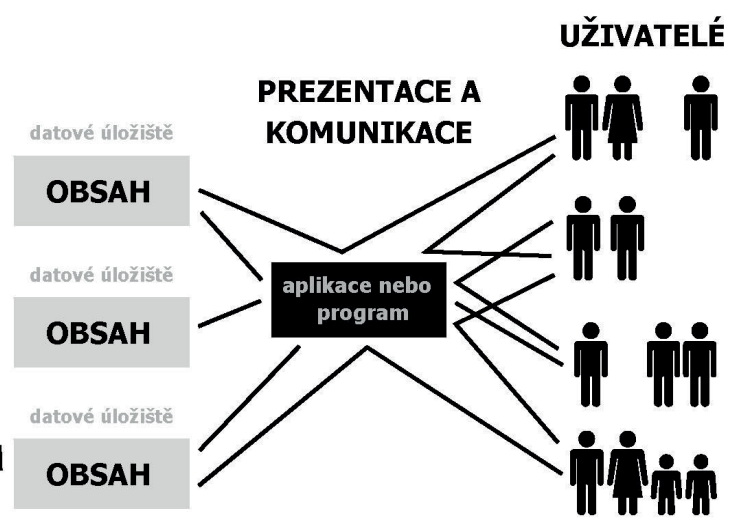

Obr. 1. Schéma tvorby multimediálního obsahu a jeho sdílení. Uživatelé (v tomto př́ípadě zájemci o památku) mají prostřednictvím aplikace a sítového připojení místo k památce př́stup $\mathrm{k}$ digitálnímu obsahu 

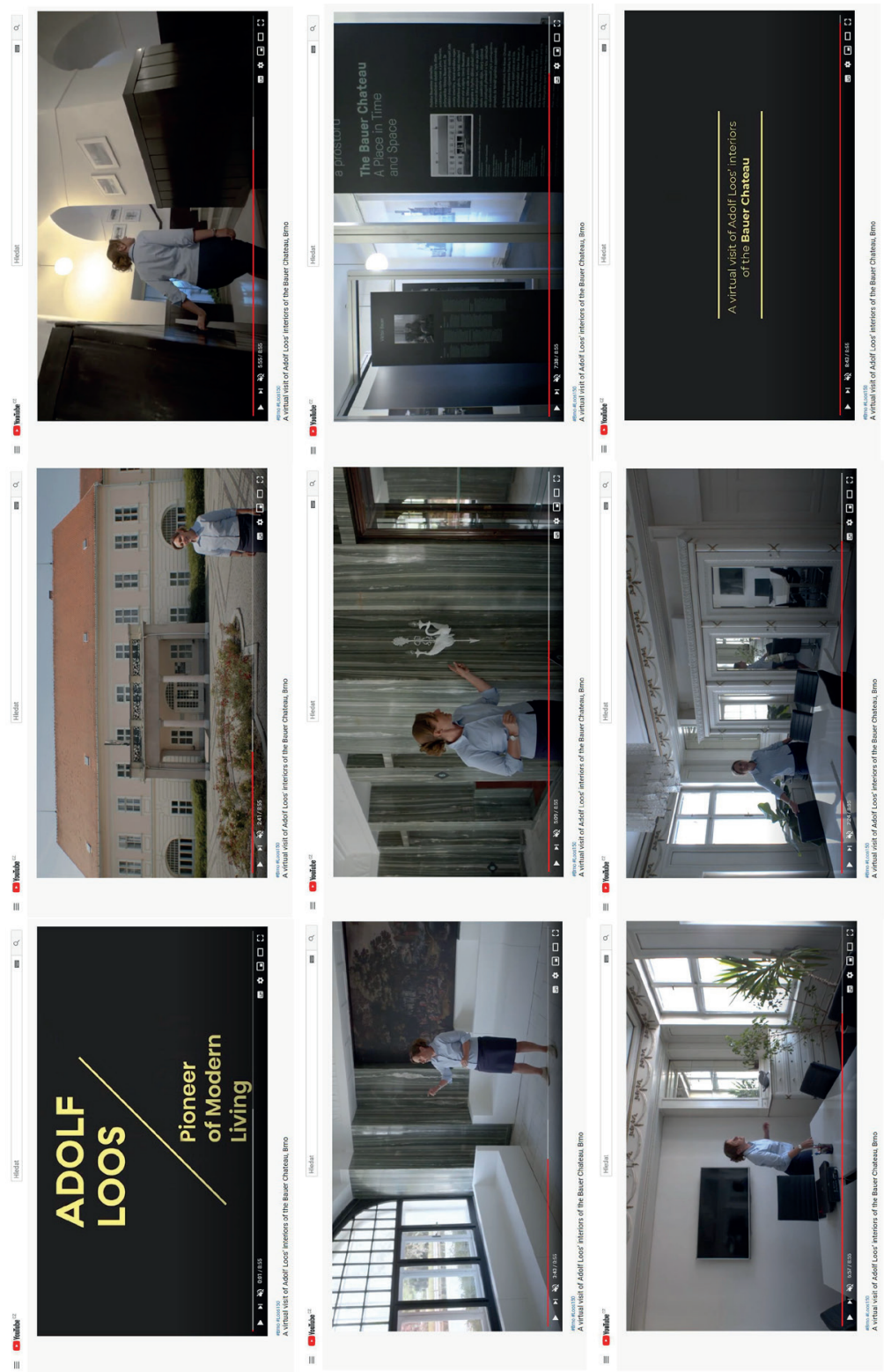

Obr. 2. Prohlídka budovy formou videa ukazuje jednotlivé místnosti, ale neposkytuje zcela přesnou představu o jejich uspořádání a vzájemných proporcích prostor 
Samotný digitální obsah může být různého typu. Tradiční obsah, který je možné sdílet, představují fotografie, dokumenty, výkresy, digitalizované archiválie a doprovodné texty. Další možností představení památky je videozáznam prohlídky objektu a nejsofistikovanější způsob představuje interaktivní virtuální model, ve kterém se uživatelé mohou pohybovat a prohlížet si ho. Zásadní rozdíl mezi prohlídkou památky formou videa a prohlížením virtuálního modelu je v tom, že videozáznam má lineární časovou stopu a uživatel se v něm nemůže pohybovat volně podle svého zájmu. Takovou prohlídku v př́ípadě brněnského Bauerova zámečku zprostředkovalo České centrum v Bruselu v rámci svého programu k výročí narození Adolfa Loose: Adolf Loos - Pioneer of Modern Living. Ukázka z prohlídky na obr. 2 ilustruje problém linearity videozáznamu a ne zcela názorného zobrazení prostoru. Výhodou videozáznamu je možnost připojení komentáře a editace záznamu před jeho zveřejněním.

Výhodou virtuálního modelu budovy oproti videozáznamu je možnost ovládání, kdy si uživatel na rozdíl od natočeného záznamu může prostor prohližet podle vlastního zájmu a uvážení. Existují dva základní typy 3D modelů. První typ představuje datový model, který může být vytvořen z jednotlivých editovatelných entit (tzv. parametrické modelování) nebo matematicky definovaných ploch a objektů (tzv. polygonové modelování). Druhým typem modelů je nasnímaný model, který je vytvořen sesazením fotografií pomocí softwaru. Rozdíl mezi těmito dvěma typy modelů je v zásadě obdobný jako mezi vektorovou a bitmapovou grafikou, tzn. první typ umožňuje přesné modelování, druhý typ prostor „pouze“ realisticky zobrazuje. V praxi přitom dochází k prolínání mezi oběma typy. Datový model může pro dosažení realistického vzhledu využívat autentických nasnímaných fotografických textur (např́klad kamenného obkladu nebo dřeva), nasnímaný model může díky infračervenému skenování a měření prováděnému současně se snímáním záznamu umožňovat některé funkce datového modelu (například měření vzdáleností a ploch). Pro hlavní sál Bauerova zámečku existuje datový 3D model, který byl vytvořen v rámci výzkumného projektu na Fakultě výtvarného umění VUT Brno9. Virtuální prohlídka tohoto modelu byla následně využita při výstavě v Muzeu města Brna ${ }^{10}$. Další ukázku prvního typu modelů nabízí v případě Bauerova zámečku 3D mapová aplikace s virtuálním modelem výstaviště provozovaná na mapovém portálu města Brna ${ }^{11}$. Jak ukazují výstupy na obr. 3 , je možné s tímto modelem manipulovat a natáčet zobrazení. Poskytuje proto dobrou představu o proporcích budovy a jejím vztahu k výstavním pavilonům a areálu výstaviště vůbec.

Druhý typ modelů, tzn. model nasnímaný speciální 3D kamerou a umožňující virtuální prohlídku prostoru hlavního sálu v zámečku12, zachycuje obr. 4 . 

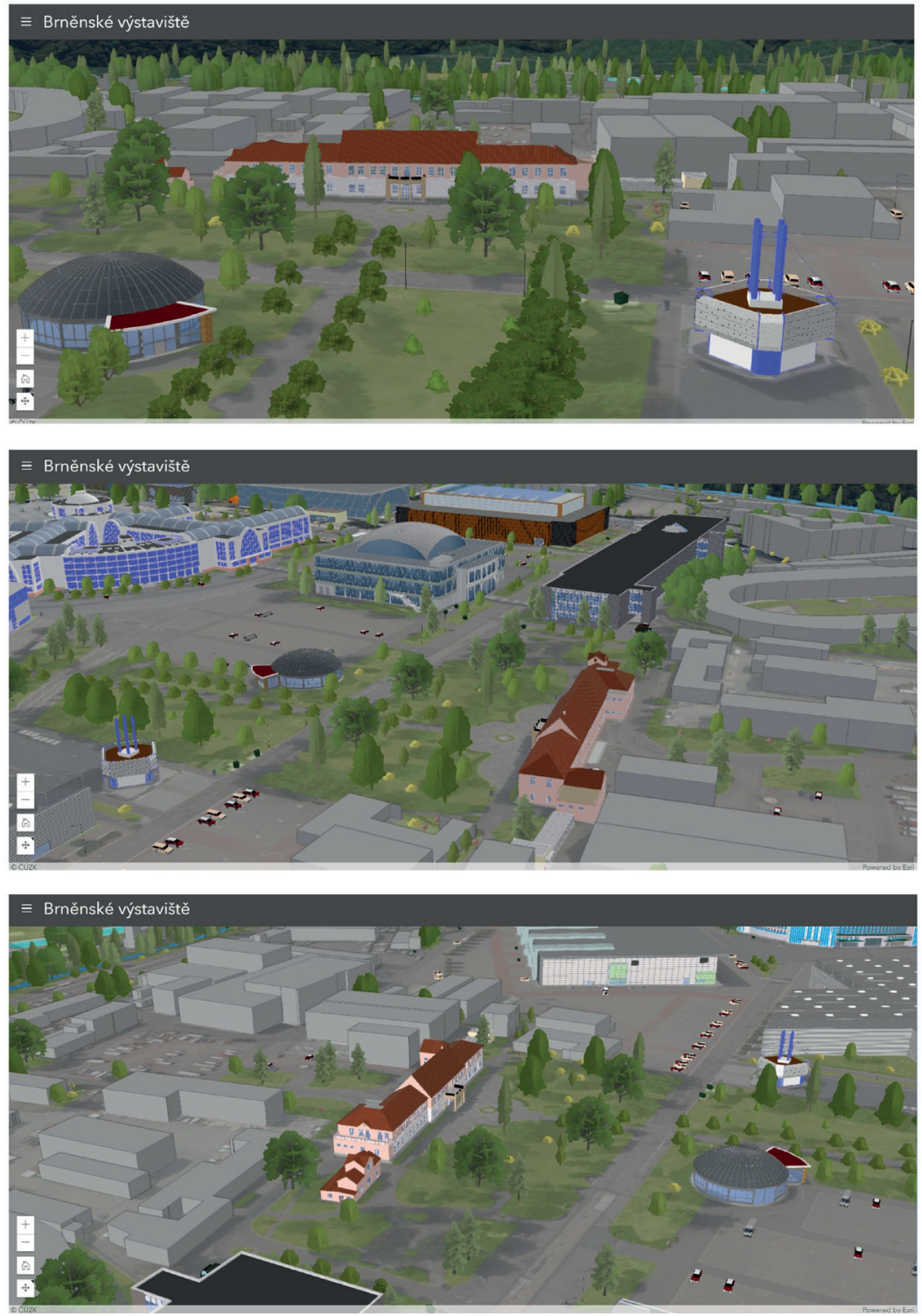

Obr. 3. Datový model výstaviště umožňuje vytvořit si jasnou představu o velikosti a proporcích budovy zámečku a staveb v jejím okolí mimo jiné díky možnosti natáčení zobrazení a přibližování pohledu 


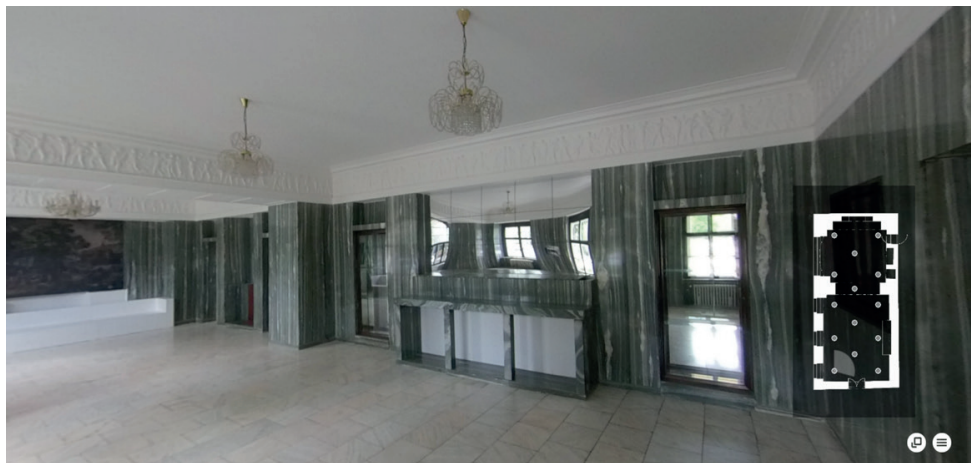

Obr. 4. Virtuální model hlavního sálu v brněnském Bauerově zámečku pořízený pomocí 3D kamery. Uživatel může měnit svoje postavení a směr pohledu; prakticky se tak může prostorem virtuálně pohybovat. Ovládací prvky pro pohyb jsou patrné v pravé části sním$\mathrm{ku}$

Takto nasnímaný model je velmi realistický a umožňuje vzdálenému uživateli utvořit si věrnou představu o podobě prostor nebo budovy. Schematicky jsou jednotlivé typy digitálního obsahu včetně 3D modelů zachycené na obr. 5 .

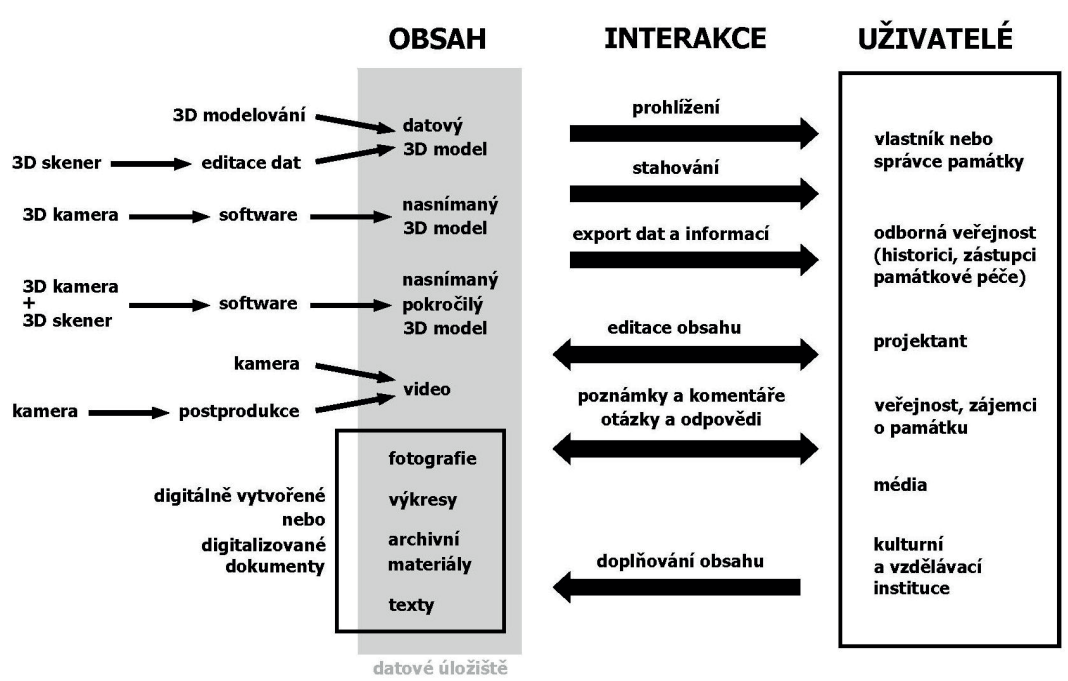

Obr. 5. Možné způsoby tvorby digitálního obsahu a možné interakce uživatelů 
Ze srovnání datového 3D modelu a 3D modelu vytvořeného pomocí snímání 3D kamerou vyplývají výhody a nevýhody obou typů modelů. Datový model je zpravidla pracnější a jeho tvorba vyžaduje vyšší odbornost a speciální software, což se odráží v jeho pořizovací ceně. Pro vytvoření výstupu (například virtuální prohlídky) je někdy nutné využít další specializovaný software, aby byl výstup př́stupný i běžným uživatelům. Velkou výhodou je však možnost využití datového modelu pro projekční práce ve stavebnictví, zejména pro tvorbu projektů založenou na modelu (tzv. building information modeling, BIM) nebo pro design a následnou výrobu atypických prvků. Zpracovatel modelu je zpravidla současně vlastníkem dat, tzn. není závislý na poskytované službě. Oproti datovému modelu je fotograficky nasnímaný model jednodušší na pořízení a tím pádem dostupnější a levnější. Je vhodný především pro prezentaci nebo jako doplněk $k$ datovému modelu. 3D modely tvořené pomocí kamery a speciálního softwaru jsou často zpracovávány v cloudu, tzn. nasnímaný záznam je odesílán po síti k poskytovateli služby, který obdržená data zpracovává na svém serveru. Nevýhodou takového řešení je závislost na poskytovateli služby, výhodou je nenáročnost zobrazení výstupů, kdy uživateli stačí sítové připojení a webový prohližeč a jeho zařízení nemusí být vybavené žádným dalším speciálním softwarem.

Oba typy 3D modelů mají určité společné rysy vyplývající z jejich digitální povahy, a problémy s tím spojené je potřeba řešit v obou př́padech. Patří sem otázka dostupnosti softwaru (například speciální aplikace) na straně koncového uživatele a př́ípadná nutnost jeho pořízení. Dále je potřeba řešit kompatibilitu různých zařízení a formátů, což může být problém zejména $\mathrm{v}$ př́ípadě spolupráce více institucí, z nichž každá už má vyvinuté vlastní řešení informačního systému nebo webové prezentace, př́ípadně zavedenou metodu projektování. Při rozhodování o pořízení 3D modelu je třeba vzít v úvahu zastarávání technologií a softwaru a zvážit časovou perspektivu využití modelu a možnost jeho budoucí aktualizace. Samostatný tematický okruh, přesahující rozsah tohoto př́spěvku, představují otázky spojené $s$ vlastnictvím dat, sdílením dat, autorskými právy $\mathrm{k}$ vytvořeným modelům a datům a problém dlouhodobé archivace dat.

Pokud jde o finální prezentaci 3D modelů a př́stup koncových uživatelů do virtuálního prostředí modelu, platí opět pro oba typy 3D modelů společná pravidla. Nezávisle na tom, zda je model datový a virtuální prostředí je vytvořeno pomocí speciálního softwaru, nebo zda jde o virtuální prostředí vytvořené pomocí počítačově sesazených fotografií s vysokým rozlišením, platí, že uživatel se může bud' pohybovat v prostředí na obrazovce počítače pomocí ovládacích prvků podobných počítačovým hrám, nebo se pohybovat přímo ve virtuální realitě prostřednictvím speciálních $3 \mathrm{D}$ brýlí pro virtuální realitu s připojeným ovládáním. Alternativou $3 \mathrm{D}$ brýlí je jednoduché zařízení v podobě plastové nebo kartonové skládačky umožňuící vsazení mobilního telefonu a jeho nasazení před oči, čímž lze rovněž docílit realistického dojmu pohybu ve virtuálním prostředí. Důležitá 
je možnost doplnění virtuálního modelu o značky, které skrývají různé odkazy, dostupné uživateli po rozkliknutí nebo ukázání ovladačem ve virtuálním prostředí.

Speciální případ virtuální reality představuje rozšířená realita (augmented reality, AR). Jde o kombinovanou prezentaci virtuálního obsahu a reálného prostředí. Rozšířená realita může být zobrazována pomocí zařízení pro virtuální realitu, na obrazovce mobilního zařízení nebo na monitoru počítače. Uživatel si tak např́ílad s pomocí 3D brýlí pro virtuální realitu může v prostoru prohlížet digitálně vymodelované objekty nebo přepínat mezi realistickým pohledem na objekt a jeho virtuálně vymodelovanou alternativní podobou. Rozšiřená realita může mít i stylizovanou výtvarnou podobu a uplatňovat se jako svébytná umělecká intervence v prostoru. Princip fungování rozšířené reality je naznačený na obr. 6 .

NÁVŠTĚVNÍCI PAMÁTKY
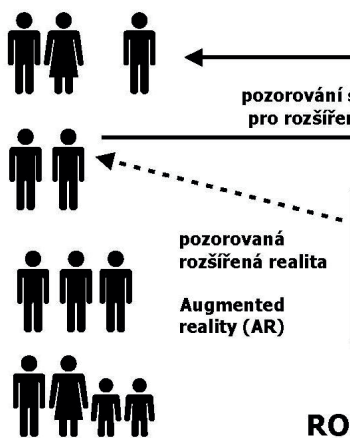

Augmented reality (AR)

reality (AR)

\section{př́mé pozorování reality}

ozorování se zařizením pro rozšr̂́enou realitu

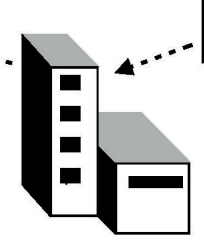

ROZŠÍŘENÁ REALITA

zařizení AR program
REALITA

aplikace nebo
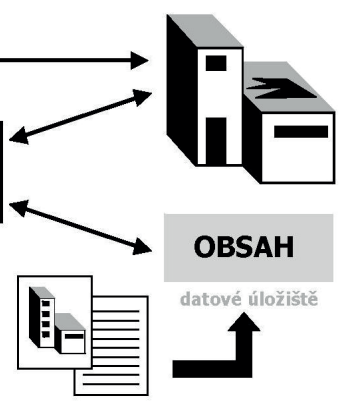

DOKUMENTACE

Obr. 6. Princip fungování rozšířené reality umožňuje např́klad zobrazit architektonickou památku v její nedochované nebo zamýšlené a nerealizované podobě

\section{Závěr}

Představení objektu zámečku na brněnském výstavišti, jeho stavební historie, badatelské historie a aktuálních aktivit s ním souvisejících ukazuje několik konkrétních případů využití informačních technologií při prezentaci architektonické památky. V budoucnu mohou být už existující virtuální modely zámečku využity pro představení objektu zahraničním odborníkům, kteří nemohou přicestovat na místo. Sdílený 3D model může fungovat také jako komunikační platforma a sloužit ke shromaždování referencí a komentářů odborníků. Datové modely bude možné využít pro projekční práce (zejména pro export pro BIM). Pro finální představení prostor po jejich rekonstrukci je možné 
do budoucna uvažovat o vytvoření rozšířené reality, díky níž bude možné přímo na místě prezentovat i nedochované části interiérového vybavení pomocí jejich 3D modelů. Na základě porovnání dosud realizovaných prezentací a zpracovaných modelů objektu se však současně ukazuje, že žádné technologické řešení není použitelné zcela univerzálně pro všechny prve jmenované účely. Některé postupy jsou vhodné pro badatele a projektanty a výměnu informací mezi nimi, současně se však přiliš nehodí pro prezentaci památky laické veřejnosti $z$ důvodu nároků na vybavení a nákladů na pořízení softwaru. Pro finální představení památky veřejnosti (at už formou nasnímané virtuální prohlídky objektu, nebo pomocí interaktivního modelu) musí být konkrétní řešení zvoleno s ohledem na tento účel.

\section{Poznámky}

1. Opatření proti šíření pandemie covidu-19v období březen-červen 2020 zahrnovala mimo jiné výrazné omezení cestování včetně mezinárodní dopravy, zákaz pořádání kulturních akcí, uzavření muzeí a památek, celkové omezení shromažd’ovaní, uzavření škol včetně univerzit a omezení provozu řady veřejných institucí.

2. Brněnské výstaviště je pod názvem „areál BVV se zámkem (Bauerova rampa)“ chráněno jako soubor objektů zapsaný v ústředním seznamu kulturních památek pod rejstříkovým číslem 47820/7 38. Dostupné online: https://pamatkovykatalog.cz/brnenske-veletrhy-a-vystavy-14762977 [cit. 26. 8. 2020].

3. Výsledky bádání shrnuté knižně viz KOŘíNKOVÁ, Jana. Adolf Loos a konfiskované vzpomínky rodiny Viktora rytíře von Bauera-Rohrfelden. Brno: Vysoké učení technické v Brně, Fakulta výtvarných umění, 2018. ISBN 978-80-214$5653-2$.

4. CHATRNÝ, Jindřich a Dagmar ČERNOUŠKOVÁ. Evropan Adolf Loos: Nejen brněnské stopy [výstava mapující Loosovo dílo na Moravě]. MUZEUM MĚSTA BRNA, 2020.

5. ŠTĚPÁNKOVÁ, Lenka [koncepce, architektonické řešení] a Jana KOŘíNKOVÁ [odborná spolupráce]. DŮM UMĚNÍ MĚSTA BRNA, Brněnský architektonický manuál [pořadatel]. Bauerův zámeček: místo v čase a prostoru [výstava]. Výstaviště Brno, zámeček, červenec-prosinec 2020.

6. CENKOVÁ, Pavla a Jana KOŘíNKOVÁ [autorky]. DŮM UMĚNí MĚSTA BRNA, Brněnský architektonický manuál [pořadatel]. Po stopách Adolfa Loose [architektonická stezka]. Brno, 2020. Dostupné online: https://www.bam.brno. cz/stezka/31-po-stopach-adolfa-loose [cit. 26. 8. 2020].

7. ČESKÉ CENTRUM BRUSEL. Adolf Loos - Pioneer of Modern Living [program k výročí]: A virtual visit of Adolf Loos' interiors of the Bauer Chateau [videozáznam prohlídky]. 2020. Dostupné online: http://brussels.czechcentres.cz/cs/ 
program/detail-akce/adolf-loos-pioneer-of-modern-living1/ [cit. 29. 8. 2020] a https://youtu.be/t0zRt8uIh7M [cit. 28. 8. 2020].

8. Pořadatelé sympozia, workshopu a spolupracující partneři: Národní památkový ústav, Centrum obnovy památek architektury 20. století; Muzeum města Brna; Magistrát města Brna, Odbor kultury; Magistrát města Brna, Odbor památkové péče; Vysoké učení technické Brno, Fakulta architektury; Vysoké učení technické Brno, Fakulta výtvarných umění; Veletrhy Brno.

9. VÁŇA, Dušan [autor modelu]. 3D model Bauerova zámečku. In: Výtvarné intervence v galerijní praxi a prezentace umění za hranicemi galerie [projekt specifického výzkumu]. Hlavní řešitel projektu: KOŘÍNKOVÁ, Jana. FAVU VUT Brno, Brno, 2018.

10. CHATRNÝ, Jindřich a Dagmar Černoušková, pozn. 4.

11. MAGISTRÁT MĚSTA BRNA, Odbor městské informatiky [ve spolupráci s Provozně ekonomickou fakultou Mendelovy univerzity]. Brněnské výstaviště [webová aplikace, 3D model]. In: mapový portál města Brna, 2020. Dostupné online: https://gis.brno.cz/esri/apps/Styler/index.html?appid=529a56b9bd08486097f4abc15972e2d7 [cit. 29. 8. 2020].

12. Pořizovatelem virtuálního modelu je architektonický ateliér Velehradský. Dostupné online: http://loos.velehradsky.cz/ [cit. 29. 8. 2020].

\section{Ilustrace}

Obr. 1 ŠTĚPÁNKOVÁ, Lenka. 2020.

Obr. 2 ŠTĚPÁNKOVÁ, Lenka [editace náhledů prohlídky]. A virtual visit of Adolf Loos' interiors of the Bauer Chateau [video]. ČESKÉ CENTRUM BRUSEL [ve spolupráci s Odborem kultury Magistrátu města Brna], 2020. Dostupné online: https:// youtu.be/t0zRt8uIh7M [cit. 29. 8. 2020].

Obr. 3 ŠTĚPÁNKOVÁ, Lenka [editace náhledů modelu]. Brněnské výstaviště [webová aplikace, 3D model]. In: mapový portál města Brna. MAGISTRÁT MĚSTA BRNA, Odbor městské informatiky [ve spolupráci s Provozně ekonomickou fakultou Mendelovy univerzity], 2020. Dostupné online: https:/gis.brno.cz/esri/apps/Styler/index. html?appid=529a56b9bd08486097f4abc15972e2d7 [cit. 29. 8. 2020].

Obr. 4 Náhled virtuálního modelu. Dostupné online: http://loos.velehradsky.cz/ [cit. 29. 8. 2020].

Obr. 5 ŠTĚPÁNKOVÁ, Lenka. 2020.

Obr. 6 ŠTĚPÁNKOVÁ, Lenka. 2020. 